\title{
O sertanejo e as experiências de inverno no Seridó Potiguar ${ }^{1}$
}

\section{The Country People and Winter Experiences in the Seridó Potiguar}

\author{
Neusiene Medeiros da SILVA* \\ Anna Jéssica Pinto de ANDRADE** \\ Cimone Rozendo de SOUZA***
}

\begin{abstract}
RESUMO
No Nordeste brasileiro, é recorrente entre os sertanejos a prática de "experiências de inverno". Estas consistem na observação de elementos da paisagem, como: a fauna, a flora, o movimento dos astros, entre outros aspectos, com a finalidade de prever chuvas ou secas. As "experiências de inverno" compõem um repertório de estratégias historicamente construídas que medeiam a relação entre os sertanejos nordestinos de regiões semiáridas e a seca. Neste artigo, analisou-se até que ponto estas experiências de inverno orientam as práticas produtivas dos agricultores familiares que habitam as regiões do sertão no Seridó Potiguar. A área de estudo compreendeu comunidades rurais dos municípios de Caicó, Acari, Parelhas e Lagoa Nova. Foram entrevistados 241 agricultores em 29 comunidades destes municípios. O estudo identificou que, apesar do alto grau de difusão de previsões meteorológicas científicas, estas não chegam a suplantar o conhecimento tradicional das experiências de inverno. Observou-se que tais experiências encontram-se bastante disseminadas entre os agricultores, exercendo funções diversas em seus modos de vida que extrapolam, e muito, a organização do sistema produtivo. Além da prevenção das intempéries ambientais e das previsões de seca ou chuvas, estas experiências desempenham um papel simbólico como intermediadoras da fé em Deus e como alimentadoras da esperança sertaneja. Portanto, as experiências de inverno praticadas por agricultores no sertão do Seridó figuram como estratégias de reprodução social de um modo de vida específico, reatualizando a esperança destes de um ano "bom de inverno", mais do que organizando suas atividades produtivas.
\end{abstract}

Palavras-chave: sertanejo; seca; experiências de inverno; meteorologia popular.

\footnotetext{
* Geógrafa (UFRN). Mestranda em Desenvolvimento e Meio Ambiente (UFRN). E-mail: neu.silva.2007@hotmail.com

"* Bacharel em Comunicação Social (UFRN). Mestranda em Desenvolvimento e Meio Ambiente (UFRN). E-mail: jessyandrade@hotmail.com

*** Doutora em Meio Ambiente e Desenvolvimento (UFPR). Professora da Universidade Federal do Rio Grande do Norte (UFRN) e pesquisadora do Programa de Pós-Graduação em Desenvolvimento e Meio ambiente (PRODEMA). E-mail: cimone.rozendo@gmail.com

${ }^{1}$ Este artigo é parte da dissertação apresentada ao Programa de Pós-Graduação em Desenvolvimento em Meio Ambiente, Universidade Federal do Rio Grande do Norte-PRODEMA/UFRN.
} 


\begin{abstract}
The practice of the so-called "Winter Experiences" by the country people is usual in the Northeast region of Brazil. It consists on the observation of landscape elements, such as fauna, flora, the stars, among others, aiming to forecast rain or droughts. The "Winter Experiences" set up a repertoire of historically constructed strategies, which mediate the relationship between country people in the semi-arid regions and droughts. In this paper, we analyze to which extent these experiences guide the productive practices of farmers living in the region of the Seridó Potiguar. The study area covers rural communities in the cities of Caicó, Acari, Parelhas and Lagoa Nova. 241 farmers in 29 communities were interviewed. This study revealed that despite the high diffusion scientific forecasts fail to overcome the traditional knowledge of Winter Experiences. It was observed that these experiences are widely spread among farmers, perform different roles in their lifestyles and extrapolate the organization of the productive system. Beyond the prevention of environmental bad elements and forecast of rain and droughts, these Experiences play a symbolic role as mediators of Faith in God and as feeders of the country people hope. Therefore, the Winter Experiences practice by farmers in Seridó figure as strategies of social reproduction of a specific lifestyle, keeping the hope of a "good winter year" rather than organizing their productive activities.
\end{abstract}

Keywords: Country People; Drought; Winter Experiences, Popular Meteorology.

\section{Introdução}

"Mandacaru quando 'fulora'na seca é o sinal que a chuva chega no sertão..." (Luiz Gonzaga, Xote das meninas)

O verso cantado por Luiz Gonzaga traduz uma das práticas de um vasto repertório cultural desenvolvido pelos sertanejos no enfrentamento das situações de seca em regiões do Nordeste brasileiro. A leitura de sinais da natureza como forma de realizar previsões climáticas ou simplesmente a realização de "experiências de inverno", como são reconhecidas, constitui um traço importante do modo de vida do sertanejo; particularmente para aqueles cuja produção depende fundamentalmente das atividades agropecuárias e, consequentemente, de condições climáticas que lhes favoreçam.

Em um cenário de grande hostilidade social e ambiental, em que a capacidade de resistência dos sertanejos é colocada à prova cotidianamente, saber ler os sinais de chuva ou seca afigura-se como uma forma simbólica de deter algum controle e precaução em um universo marcado pela imprevisibilidade. Neste contexto, estas experiências representam a possibilidade de expansão de existência dos agricultores sertanejos. São estratégias reproduzidas e ressignificadas em cada momento histórico.

Não por acaso, estas práticas se eternizaram nos versos de Luiz Gonzaga. Ler "o sinal que a chuva chega no sertão" é experiência vivenciada e compartilhada pela grande maioria dos sertanejos. Entre estes, há também os que se notabilizaram por esta habilidade e foram, por isto, socialmente identificados como "profetas da chuva". Durante muito tempo, seus prognósticos ou "profecias" eram as únicas informações que norteavam as práticas produtivas dos agricultores de regiões semiáridas. Mas, qual seria o papel destas experiências de inverno, considerando o quadro atual de crescente racionalização destes aspectos, sobretudo com a disseminação das previsões meteorológicas científicas? Neste artigo, buscou-se compreender até que ponto esta forma de conhecimento ainda orienta as práticas produtivas dos agricultores que habitam a região do Seridó Potiguar.

A região do Seridó Potiguar (Figura 1) foi historicamente constituída por 23 municípios ${ }^{2}$ e está localizada na porção centro-meridional do Estado do Rio Grande

\footnotetext{
2 São eles: Acari, Caicó, Carnaúba dos Dantas, Cerro Corá, Cruzeta, Currais Novos, Equador, Florânia, Ipueira, Jardim de Piranhas, Jardim do Seridó, Jucurutu, Lagoa Nova, Ouro Branco, Parelhas, Santana do Seridó, São Fernando, São João do Sabugi, São José do Seridó, São Vicente, Serra Negra do Norte, Tenente Laurentino Cruz e Timbaúba dos Batistas. Essa delimitação do Seridó é resultado do contexto histórico, cultural e identitário de produção do espaço e em sua estruturação e reestruturação (MORAIS, 2005).
} 


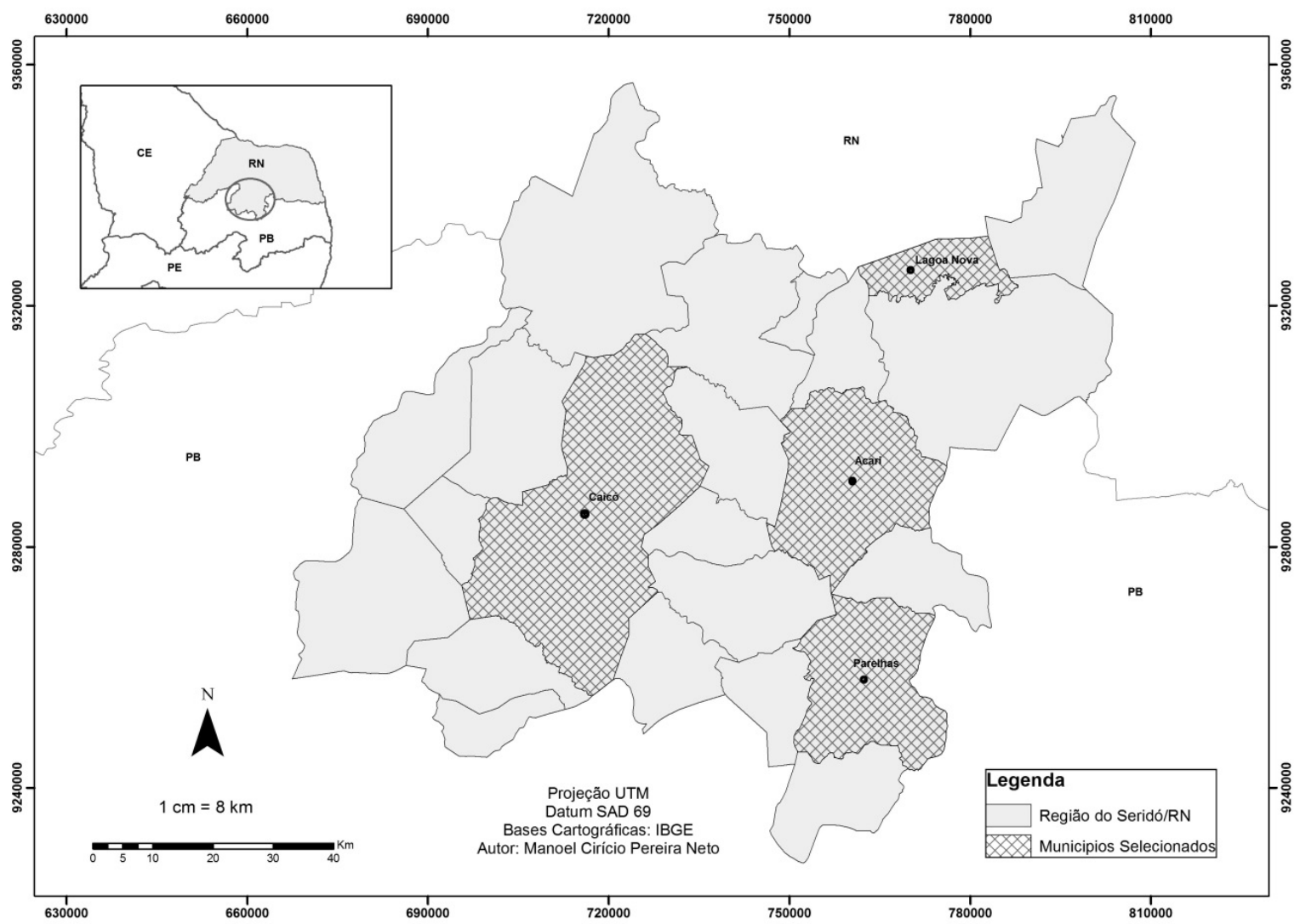

FIGURA 1 - Municípios de Caicó, Parelhas, Acari e Lagoa Nova no Seridó Potiguar/RN

Elaborado por Manoel Cirício Pereira Neto, 2013.

do Norte (MORAIS, 2005). A escolha desta área se deu em razão do forte caráter identitário de sua população, aspecto sublinhado em toda literatura sobre sua formação e ocupação. Além disso, segundo Taddei (2009), nela se encontram os mais "célebres profetas da chuva".

A pesquisa envolveu entrevistas com 241 agricultores em 29 comunidades rurais ${ }^{3}$ nos municípios de Caicó, Acari, Parelhas e Lagoa Nova. Os questionários buscaram caracterizar socioeconomicamente a população, bem como identificar a diversidade de experiências de inver- no. A pesquisa teve um caráter qualitativo e utilizou-se como método a Análise de Conteúdo proposta por Bardin (2010), por meio da categorização. Foram entrevistados os sertanejos do Seridó Potiguar, constituídos em sua maioria por agricultores e pescadores. Neste estudo, as denominações sertanejo, agricultor e seridoense estão sendo utilizadas de forma complementar, ou seja, uma não exclui a outra.

$\mathrm{O}$ artigo está organizado da seguinte maneira: na primeira parte, o texto traz uma discussão conceitual

\footnotetext{
${ }^{3}$ Os critérios de seleção dos municípios e das comunidades estão detalhados com profundidade no texto da dissertação intitulado Experiências de inverno no Seridó Potiguar, referenciado no final do artigo.
} 
sobre as experiências de inverno e o cenário em que elas se desenvolvem, concebendo o sertão e o sertanejo a partir da perspectiva de Diegues e Arruda (2001) e Guillen (2002), enquanto comunidade tradicional, e sua participação na construção da identidade brasileira. As experiências de inverno foram abordadas utilizando autores como Araújo et al. (2005), Bruno e Martins (2008), Folhes e Donald (2007), Macedo (1998), entre outros. Para compreender o processo de desenvolvimento das experiências de inverno, discorreu-se sobre os conceitos de paisagem de Santos (1997), Berque (1998), Sauer (1998), Cosgrove (1998) e a experiência de Tuan (1983).

A segunda parte trata do estudo empírico da pesquisa, apresentando a caracterização dos aspectos produtivos e econômicos das comunidades estudadas, os elementos que configuram o seu modo de vida e o quadro atual do conhecimento sobre as experiências de inverno, a saber: seus elementos, sinais indicativos, formas de previsão e suas funções no modo de vida dos sertanejos.

\section{O saber sertanejo: as experiências de inverno}

Recentemente, autores como Taddei $(2006,2009)$, Folhes e Donald (2007), Araújo et al. (2005), Bruno e Martins (2008), Magalhães (1963) e Lucena et al. (2005) elaboraram estudos a respeito dos sertanejos e suas experiências de inverno. Segundo estes autores, quase todo sertanejo detém algum conhecimento de tais experiências. Mas são os conhecidos como Profetas da chuva, Profetas do Inverno, Profetas da Natureza e/ou Profetas do Sertão que detêm o maior conhecimento.

Na conjuntura das experiências de inverno, o clima é o elemento fundamental para o seu desenvolvimento. Especificamente, a condição climática azonal do Nordeste em relação a outras regiões do Brasil caracteriza-se por um sistema meteorológico complexo, reduzindo as possibilidades de acerto das previsões meteorológicas. Em conformidade com Folhes e Donald (2007, p. 20), o sertanejo busca conviver com as adversidades naturais usando seus conhecimentos empíricos como estratégia de sobrevivência. A seca estaria no "centro de sua estratégia econômica e de vida, para, assim, minimizar o risco de perdas e de fracasso na produção dos meios de sobrevivência".

Nesse contexto, o conhecimento dos sertanejos que vivem na zona rural do sertão nordestino em relação às experiências de inverno apresenta-se como uma das estratégias para minimizar os riscos e prejuízos que as secas poderiam causar. O Sertão do Seridó ou os Sertões do Seridó, como diria Faria (1980), apresenta-se como um espaço de referência para estudos relacionados às experiências de inverno, uma vez que lá residem muitos Profetas-celebridades $^{4}$ (TADDEI, 2009).

Foi na convivência com os elementos paisagísticos dos sertões que o sertanejo da zona rural desenvolveu as "experiências de inverno", as quais consistem na observação sistemática da natureza para prever o tempo. Conforme se observou anteriormente, a realização destas experiências está ligada principalmente à ocorrência de secas periódicas na região. Os sertanejos fazem uso de diversos elementos paisagísticos para realizar suas previsões, como: o comportamento da fauna, da flora da caatinga, o movimento dos astros, entre outros. Como qualquer conhecimento tradicional, as experiências de inverno são repassadas de geração a geração no processo de hierarquização dos mais velhos para os mais jovens.

$\mathrm{Na}$ literatura sobre as experiências de inverno, são identificados os protagonistas destas experiências, a saber: primeiramente, a figura do sertanejo agricultor, que, ao longo do tempo e espaço, apreendeu esse saber, e os chamados "profetas", pessoas da comunidade reconhecidas publicamente pela habilidade na realização das experiências. Estes foram nomeados por Taddei (2009) como Profetas da Chuva, Profetas do Sertão ou "Profetas-celebridades", termo adotado pelo autor para distinguir entre os profetas aqueles cujo conhecimento é veiculado em meios midiáticos de massa (rádio e televisão).

No sertão de clima desfavorável à reprodução do sertanejo que habitava o espaço rural, este aprendeu a viver e a conviver com a natureza. É por meio da

\footnotetext{
${ }^{4}$ Profetas-celebridades são aqueles cuja notoriedade, no conhecimento destas experiências de inverno, provém do seu acesso e divulgação deste saber nos meios midiáticos.
} 
observação sistemática desta que as experiências de inverno surgem enquanto alternativa de convivência. As observações são instigadas pela incerteza da condição climática e mais precisamente pela ocorrência de uma possível seca nos sertões.

\subsection{Do palco aos atores: o sertão e o sertanejo}

O Sertão é um termo recorrente usado para classificar as terras interioranas do Brasil desde o período colonial, mas que penetra o imaginário dos brasileiros até os dias atuais. Esta categoria influenciou na construção de uma identidade nacional presente nas obras de diversos intelectuais (GUILLEN, 2002). Considerando o sertão enquanto uma construção simbólica, Guillen analisa a obra de Capistrano de Abreu para mostrar como essa categoria foi fundamental para a formação da identidade brasileira.

Com a chegada dos europeus no século XVI, essa identidade começou a se firmar por meio da sua penetração no interior do país. E isso se "[...] constitui como um dos fundamentos com os quais viria construir os alicerces da história da nação, e suas contribuições para a construção simbólica da nacionalidade brasileira [...]" (GUILLEN, 2002, p. 106). Assim, o sertão e o sertanejo entram como protagonistas da "brasilidade" através das suas características bastante peculiares e "autênticas". No esforço de definir uma identidade nacional, os intelectuais abordados por Guillen consideraram o espaço, a territorialidade e a natureza como fundamentais para esta definição (GUILLEN, 2002).

Também Morais (2005, p. 25) evidencia que “[...] Nos primórdios, o nome Sertão prevalecia sobre os demais ao remeter-se à imensidão do interior nordestino, caracterizada pela semiaridez. Com a ocupação e apropriação das terras, foram surgindo recortes no espaço sertanejo que passou a comportar vários sertões, dentre dos quais o Sertão do Seridó". A utilização do termo sertão vinculava-se a condições naturais específicas, mas aos poucos passa a designar também o caráter dos habitantes que vivem nesse espaço.

Nesse contexto, a natureza era vista de forma polarizada: "infernal ou paradisíaca". Do mesmo modo, ao sertão foram atribuídos adjetivos "negativos e positi- vos". Essa região, no período da colonização, era vista como uma área inóspita de difícil ocupação, haja vista o pequeno número de colonizadores e a lentidão deste processo. Contudo, este foi cenário de vários estudos de literatura e historiografia, a exemplo da obra Os sertões, de Euclides da Cunha, que retratou a Guerra de Canudos na Bahia (GUILLEN, 2002).

Até o final do século XIX, o sertão ainda era uma categoria que designava todo o interior do país, portanto, não havia apenas um sertão, mas vários sertões. Somente com o movimento regionalista do início do século XX é que o sertão nordestino passou a ganhar maior visibilidade perante as outras regiões (ALBUQUERQUE JR., 1999), principalmente o Sudeste.

A colonização do sertão nordestino deu-se por meio da pecuária, que deu origem às vilas, mais tarde alçadas à categoria de cidades. A população que habitava esse meio foi, então, chamada de sertaneja, sendo considerada pessoa de caráter forte, destemida, desbravadora, que vivia sua própria vida distante da civilização (litoral). Uma sociedade do couro, onde essas pessoas possuíam costumes, comidas, hábitos, modos de produção, religiosidade, vestimentas bastante peculiares à região (DIEGUES; ARRUDA, 2001).

São os versos do cordelista sertanejo que nos dizem sobre o que é o sertão, sua gente e seus temores:

Sertão terra de encanto
de amor, paz e alegria
de ar brando e mais tocante
brisa mansa, leve e fria
onde a natureza em tudo
inspira mais poesia (SANTOS, 19--, p.1)
Sertão terra de homens fortes
honestos e conceituados
corajosos e sinceros
onde têm sido criados
os melhores cantadores
e poetas inspirados (SANTOS, 19--, p. 2)

Quando a temida seca atinge o sertão:

Ver-se o gado morrendo de fome, sede e maus tratos 
roídos por carrapatos os ossos aparecendo seu dono se maldizendo sem encontrar a solução é grande a lamentação para todo sertanejo não há coalhada e nem queijo quando há seca no sertão (SANTOS, 1981, p. 1)

Nesses versos, é visível como a questão natural mostra-se crucial para a vida sertaneja no século XX. Por vezes, bela e inspiradora, por outra, fenômenos naturais, como a temida seca, transformam esse ambiente num espaço de sofrimento, fome, sede, migração e morte. Em outros tantos versos, há também referências recorrentes à capacidade de resistência do sertanejo, muitas vezes comparada à da própria caatinga.

Segundo Diegues e Arruda (2001, p. 50), os sertanejos “[...] ocupam a orla descontínua do Agreste e avançam nas áreas semiáridas das caatingas. Penetrando no Brasil central, atingiram campos cerrados que se estendem por milhares de quilômetros quadrados". No período de ocupação do interior do Brasil, desenvolveram a criação de gado para fornecer carne, couro e bois para a produção açucareira. Com a atividade de pastoreio, o sertanejo ocupou em três séculos quase todo o sertão brasileiro. Foi o seu modo de viver que o constituiu enquanto população tradicional.

\subsection{Conhecimentos tradicionais dos sertanejos}

Conceitualmente população tradicional remete a "[...] grupos humanos diferenciados sob o ponto de vista cultural, que reproduzem historicamente seu modo de vida, de forma mais ou menos isolada, com base na cooperação social e relações próprias com a natureza" (DIEGUES; ARRUDA, 2001, p. 27). Dessa forma, o modo de vida que o sertanejo desenvolveu nos sertões lhe caracteriza como uma população tradicional com seu saber-fazer próprio em relação à natureza sertaneja. O sertanejo do Nordeste é um grupo que possui grande conhecimento sobre a natureza e seu funcionamento. Os saberes sobre o meio em que está inserido contribuem, por vezes, para a proteção e conservação da natureza.
No Brasil, especificamente nos Estados da Bahia e de Alagoas, a Esperança, da ordem Orthoptera e família Tettigoniidae, é um inseto que, segundo relatos de um alagoano, traz bons presságios ou não, dependendo de sua coloração: verde traz boa sorte, a boca preta representa azar. Na Bahia, sua aparição está atrelada somente à boa sorte, mas de modo geral esta é relacionada à esperança. $\mathrm{O}$ relato conta que a Esperança é abençoada porque rezava para Maria no momento do nascimento do Menino Jesus. Pedia que Maria tivesse um parto em paz. Então ninguém pode matá-la e, caso alguém o fizesse, perderia a esperança (MARQUES, 2005). Nesse contexto, essa crença atua como um mecanismo de preservação desse inseto, ou seja, provavelmente este não entrará em extinção.

A flora é outro elemento que tem sido utilizado pelos sertanejos para as mais diversas finalidades ao longo da história. Roque (2009) registra sete categorias de uso da flora da caatinga em comunidade rural no município de Caicó, dentre estas: medicinal, alimentícia, madeireira, mística, combustível, forrageira e uso doméstico.

A experiência de inverno é um dos conhecimentos tradicionais que o sertanejo do Nordeste angariou em sua relação com o meio ambiente, o qual faz uso, principalmente, da fauna e da flora na elaboração dos prognósticos. $\mathrm{O}$ "conhecimento tradicional é definido como o conjunto de saberes e saber-fazer a respeito do mundo natural e sobrenatural, transmitido oralmente, de geração em geração" (DIEGUES; ARRUDA, 2001, p. 31). Na literatura sobre o tema, são constantes as referências sobre a importância deste savoir faire para a conservação da natureza, para o uso sustentável da diversidade biológica e para o conhecimento científico.

Na observação e na aplicação deste conhecimento, a paisagem dos sertões comporta os elementos necessários a esses processos. É por meio desses elementos (flora, fauna, astros etc.), que o sertanejo elabora suas previsões de "inverno" para os sertões.

\subsection{Conceito de paisagem e a produção da paisagem sertaneja}

Na literatura sobre paisagem, Sauer (1998) define dois tipos: a natural e a cultural ou geográfica. A paisagem natural é aquela constituída por elementos físicos que não 
sofreram ação do homem sobre os mesmos. Esse tipo de paisagem em sua totalidade não existe mais em grande parte do mundo. A paisagem cultural refere-se às formas produzidas pela ação do homem sobre a paisagem natural.

A paisagem é formada por um conjunto de elementos que, quando juntos, apresentam "inter-relações". Se considerados no conjunto, formam uma realidade que não seria possível se vista em suas partes separadamente, ou seja, é necessário para sua compreensão vê-la como uma unidade (SAUER, 1998).

Existe, primeiramente, a partir do sentido dado à mesma pela sociedade que a "produz, reproduz e transforma". Nesse sentido, Berque (1998) classifica-a como "marca", por expressar os traços de uma sociedade sobre a natureza, e "matriz", porque interfere, até certo ponto, no modo como é percebida e nos processos de produção, reprodução e transformação.

Por sua vez, na análise das paisagens, Cosgrove (1998) insere em sua leitura a cultura e o simbolismo, inserção que o diferencia dos demais autores em suas abordagens sobre o tema. "A paisagem, de fato, é uma 'maneira de ver', uma maneira de compor e harmonizar o mundo externo em uma 'cena', em unidade visual" (COSGROVE, 1998, p. 98). A cultura imprime objetos na paisagem adquirindo importância simbólica para a mesma.

Até os elementos naturais das paisagens passam a ser "produtos culturais" quando lhes é atribuído um significado; contudo, não perdem suas propriedades naturais, passando, desse modo, a ser uma paisagem cultural. E qualquer intervenção humana na natureza a transforma em cultura. A partir desse pensamento, afirma-se ser necessário entrarmos na "consciência cultural" dos outros para que se possa revelar o significado dessa paisagem cultural (COSGROVE, 1998).

Na concepção de Santos, a paisagem é "tudo aquilo que nós vemos, o que nossa visão alcança. Esta pode ser definida como o domínio do visível, aquilo que a vista abarca. Não é formada apenas de volumes, mas também de cores, movimentos odores, sons etc." (SANTOS, 1997, p. 61).

Resulta de movimentos superficiais de fundo da sociedade, uma realidade de funcionamento unitário, um mosaico de relações, de formas, funções e sentidos (SANTOS, 1997, p. 21). Dependendo de onde se observa a paisagem, ela toma escalas diferentes. Quanto mais o sujeito sobe em altura, mais a visão se amplia, reduzindo o número de obstáculos que se apresentam. Sua dimensão é a da percepção, ou seja, o que os sentidos podem captar da mesma.

A percepção por si não se pode chegar ao conhecimento, sendo necessária a sua interpretação. Toda percepção é seletiva e depende do aparelho cognitivo para a apreensão. Portanto, cada sujeito pode apresentar versões distintas sobre o mesmo fato. Por exemplo, o que o sertanejo percebe observando a paisagem no dia santo de São José (19 de março), comparando-o com o morador da cidade que esteja no mesmo espaço, provavelmente será diferente. Contudo, a realidade é apenas uma, mas cada pessoa a percebe e interpreta de forma diferenciada.

A paisagem é apreendida pelos sentidos do corpo (aparelho cognitivo) e divide-se em dois tipos: natural e artificial. A paisagem natural seria aquela pela qual o homem não a modificou, sendo praticamente quase impossível sua existência. Já a paisagem artificial é aquela que sofreu transformações pela ação do homem (SANTOS, 1997).

Mesmo em lugares aos quais os homens ainda não tiveram acesso, contudo, podem existir interesses econômicos e políticos sobre os mesmos. O que se vê é a mistura de elementos naturais e artificiais formando uma paisagem heterogênea. Devido à presença do homem encontrar-se suficientemente disseminada em boa parte dos lugares do planeta, é quase impossível existir uma paisagem essencialmente natural.

A paisagem não é estática, pois está em permanente mudança. Seu movimento pode ser rápido ou não, dependendo da capacidade de modificação do homem. Sua apreensão se dá pela percepção, mas seu entendimento passa pela interpretação, tornando-se aguçada por meio da experiência acumulada. Diante destas considerações, neste artigo adotou-se a perspectiva de paisagem proposta por Berque (1998), entendendo nesta abordagem que o sertanejo é ele próprio o elemento desta paisagem.

É na leitura dos elementos das paisagens dos sertões que as experiências de inverno são desenvolvidas. Para se entender o significado do termo experiência, ${ }^{5}$

\footnotetext{
${ }^{5}$ A "experiência de inverno" é uma expressão própria do sertanejo para nomear o seu conhecimento a respeito dos elementos que compõem a paisagem. Nesse sentido, o conceito de experiência de Tuan (1983) mostra-se oportuno para entender a realidade presente.
} 
convencionou-se adotar o conceito de Tuan (1983, p. 9), segundo o qual esta "[...] abrange diferentes maneiras através das quais uma pessoa conhece e constrói a realidade. Estas maneiras variam desde sentidos mais diretos e passivos, como o olfato, paladar e tato, até a percepção visual ativa e a maneira indireta de simbolização".

Nesse sentido, a experiência consiste em apreender a realidade através da vivência cotidiana no meio em que se está inserido, utilizando um ou mais sentidos na apreensão. Tuan (1983) ressalta ainda que as pessoas em sua maioria fazem uso dos cinco sentidos na apreensão da realidade. No contexto do sertão, visto como um espaço paradisíaco ora infernal, onde o homem via-se submetido às intempéries da natureza em virtude do contato mediado pelo trabalho, este, por sua vez, aprendeu a utilizar os seus sentidos na apreensão dos sinais que a natureza transmitia e transmite.

O entendimento das relações homem e meio é fundamental para se compreender os caminhos do desenvolvimento das sociedades nas diversas faces ao longo do tempo e do espaço. O uso dos elementos que compõem o meio natural ou artificial oferece, em parte, matéria para a compreensão deste desenvolvimento. Em exemplo, a fauna foi utilizada ao longo da história pelos povos da antiguidade para diversos fins zooterápicos na cura de enfermidades (ALMEIDA, 2005). Às vezes essa categoria está associada às crenças religiosas dentro das sociedades em formas de tabus. Nessa condição, o uso de tais espécies está condicionado por uma questão sociocultural, que auxilia no processo de etnoconservação das mesmas e, consequentemente, no equilíbrio ambiental.

\subsubsection{Clima: elemento fundamental da dinâmica da paisagem nos sertões}

A pluviosidade do Nordeste está intimamente relacionada aos sistemas de grande escala: Zona de Convergência Intertropical (ZCIT) e os sistemas frontais, responsáveis por cerca de 30 a $80 \%$ da pluviosidade, variando em relação ao local observado. Os demais $20 \%$ dividem-se entre os sistemas de mesoescala (perturbações ondulatórias no campo dos ventos alísios, complexos convectivos e brisas marítima e terrestre) e microescala (circulações orográficas e pequenas células convectivas). A ZCIT é resultado da convergência dos ventos alísios de NE e SE provenientes, respectivamente, dos sistemas de alta pressão dos hemisférios norte e sul, a qual se concentra numa faixa de $2^{\circ}$ a $4^{\circ}$ de latitude Sul durante os meses de março a abril (MOLION; BERNARDO, 2002).

Esse sistema é o principal responsável especificamente pelas chuvas dos Estados do Norte-Nordeste (Nor-Nordeste-NNE) - Ceará e partes do Rio Grande do Norte, Piauí, Maranhão e oeste da Paraíba e de Pernambuco. Sua influência sobre as chuvas no NNE vai variar de acordo com a sua posição mais ao hemisfério Norte (seca) ou mais para o hemisfério Sul (chuva) (MOLION; BERNARDO, 2002). A condição semiárida do Nordeste é agravada pelas ocorrências das secas periódicas, que, segundo esses autores, se devem às variações no sistema de grande escala e possivelmente mecanismos externos ao sistema terra-atmosfera-oceano. Dessa forma, as causas da seca estão relacionadas ao fenômeno El Niño no Pacífico sul, às manchas solares e às erupções vulcânicas.

Guerra (1981) define a seca enquanto "um fenômeno que se caracteriza como a ausência ou má distribuição das chuvas", "[...] tendo uma ocorrência cíclica ao longo da história" (MORAIS, 2005, p. 119). Ainda segundo Guerra (1981, p. 34) “[...] as seccas nestes sertões são necessárias, muito principalmente dadas por uma sabedoria infinita que não pode errar, que tudo dispõe para bem de seus filhos". O fenômeno faz com que os sertanejos desenvolvam saberes, que lhes permitirão viver no espaço de ocorrência do fenômeno. "Seja como for, pode-se dizer que não há sertanejo que se furte à influência das experiências, o meio em que ele vive o tem predisposto" (GUERRA, 1981, p. 15).

De clima semiárido, ocorreram naturalmente as secas periódicas, que provocaram grandes prejuízos, tanto materiais como humanos. A seca de 1877-1879 foi considerada um marco na formulação de ações voltadas no combate ao fenômeno (SILVA, 2003). Porém, décadas depois, as ações por parte dos governantes não chegavam a todos os afetados e a ausência de aparato tecnológico de previsão meteorológica, para antecipar quando tais eventos poderiam ocorrer, contribuiu para um quadro de calamidades.

Diante dessa conjuntura, o sertanejo tinha uma única opção: buscar no meio em que estava inserido as 
respostas para as suas ansiedades. E isto se constituía em ler o que estava escrito na paisagem e não somente na leitura do que estava visível, mas também o invisível aos olhos. Dessa forma, os sertanejos seridoenses têm grande interesse em entender como funcionam e interagem os elementos da paisagem.

De um modo geral, as condições de solo e clima nos sertões fizeram do Bioma Caatinga um laboratório de estudo, apresentando inúmeras características adaptativas às condições climáticas. Essas experiências são resultados das secas ocorridas na região, imprimindo no sertanejo seridoense a necessidade de prever o tempo para se proteger de suas consequências.

\subsubsection{Caatinga}

No cenário paisagístico dos sertões do Nordeste, devido às condições climáticas e de solo, a caatinga é o bioma que ocupa a maior parte da região, sendo exclusivamente brasileiro. São $935 \mathrm{mil} \mathrm{km}^{2}$ de vegetação de caatinga (SAMPAIO; RODAL, 2000) distribuídos pelos Estados do Piauí, Ceará, Rio Grande do Norte, Paraíba, Pernambuco, Alagoas, Sergipe e Minas Gerais (SAMPAIO et al., 2002, apud MAIA, 2004).

A vegetação de caatinga, em face das condições climáticas do semiárido, apresenta várias adaptações que facilitam na redução da perda de água por evapotranspiração. O termo caatinga significa na língua tupi mata branca, pois, no período da estiagem, que compreende os meses de julho a dezembro, esta se mantém em sua maior parte despida de folhagem, permanecendo em estado de dormência à espera do cair das primeiras chuvas. As espécies que apresentam tal adaptação são chamadas de caducifólias. Durante todo o ano têm-se espécies florando e frutificando para alimentar a fauna que habita essa região. Na estiagem, de vegetação aparentemente morta, veem-se pontos verdes contrastando com o seco. Estes pontos verdes são as espécies perenifólias, caracterizadas por permanecerem com as folhas verdes durante todo ano, servindo de refúgio para algumas espécies da fauna das altas temperaturas do ambiente (MAIA, 2004).

Certas espécies apresentam caules verdes, que fazem a fotossíntese, como a Embiratanha (Pachira marginata A. St.-Hill.); outras armazenam água por meio de tubérculos em suas raízes como o Cumaru (Amburana cearensis (Allem.) A. C. Smith e o imbuzeiro (Spondias tuberosa Arruda). Caules são geralmente de tons branco-acinzentados, que refletem a luz do sol. As folhas são, em sua maioria, pequenas e, quando em horários de alta insolação, fecham os estômatos, evitando a perda da água por evapotranspiração; outras já são aveludadas. Em geral, a caatinga apresenta mecanismos adaptativos, os quais lhe permitem sobreviver numa região semiárida sujeita a períodos de estiagem de seis meses até longos e severos anos de seca (MAIA, 2004).

Foi nesse ambiente que o sertanejo, por meio das "atividades pastoris, nas condições climáticas dos sertões, cobertos de pastos pobres e com extensas áreas sujeitas a secas periódicas, conformaram não só a vida, mas também a própria figura do homem e do gado" (DIEGUES, ARRUDA, 2001, p. 50). Na mesma linha de pensamento, Ab'Sáber (2003, p. 91) afirma que "para o cotidiano do sertanejo e sobrevivência de sua família, o fator interferente mais grave reside nas irregularidades climáticas periódicas que assolam o espaço social dos sertões secos". Mesmo com a criação de políticas de combate e depois de convivência com as intempéries do clima, o sertanejo, em sua maioria, permanece desamparado.

\section{Dos aspectos produtivos e econômicos das comunidades estudadas}

Os sertanejos do Seridó desenvolvem diversas atividades, como agricultura, pecuária, pesca, prestação de serviços, além de muitos contarem com os benefícios do governo (aposentadorias e bolsa-escola). Essa diversidade produtiva que o seridoense de um modo geral apresenta é resultado das crises dos ciclos econômicos do algodão e da mineração ao longo de sua história de formação, estruturação e reestruturação, sendo "substituída por uma economia diversificada" (MORAIS, 2005, p. 280).

Em relação à produção agropecuária, o uso do solo está relacionado à criação de bovinos (corte e leiteiro), caprinos, ovinos e suínos. Os sujeitos entrevistados nesta pesquisa geralmente desenvolvem mais de um tipo de criação. As aves (galinhas, frangos, pintos etc.) e os bovi- 
nos foram os rebanhos com o maior número de criadores, enquanto o caprino praticamente ninguém criava. As aves e os bovinos são as criações mais representativas.

A criação dos rebanhos dá-se de três formas: extensiva - solto na caatinga, intensiva - confinados em chiqueiros/currais, e semi-intensiva - parte do dia os animais ficam confinados e na outra são soltos no cercado para pastagem. Contudo, a criação no regime extensivo é mais expressiva em relação às outras formas.

A dieta dos animais no período da estiagem (julho a dezembro) é constituída de pasto de sequeiro (caatinga), que surge ao cair das primeiras chuvas, se estendendo até os primeiros meses de estiagem, dependendo do regime pluviométrico; ração de armazém (pasta de algodão, farelo de trigo, babaçu, casquinha, soja); pasto irrigado/ vazante e pasto molhado do riacho (capim: elefante, braquiara, ceará, tangana, taboca, taquari), rama (batata, feijão, cebola, mandioca); cactáceas (mandacaru, xiquexique, palma), sobras de comida (soro de queijo e palha de milho seco, alimento humano). A comercialização dos rebanhos é realizada principalmente por meio de atravessadores, diretamente ao açougue local e ao consumidor.

A produção agrícola é desenvolvida em três formas: sequeiro (praticada nos meses chuvosos da região), vazante (realizada no entorno dos corpos d'água na medida em que estes vão secando) e irrigada (corresponde em aguar a produção por meio de canais, que levam água de algum reservatório, principalmente no período da estiagem). Por vezes, os sertanejos praticam uma ou mais formas de produção. Identificou-se que a produção de sequeiro é a mais exercida entre os entrevistados, seguida da vazante e irrigação. Tal premência os torna mais vulneráveis às instabilidades ambientais. Segundo dados da pesquisa, o clima já causou prejuízo a $68,5 \%$ dos entrevistados. Os eventos citados como principais causadores dos prejuízos foram a seca e as inundações. Dentre os tipos de prejuízos estão a perda da lavoura, seguidos da perda de animais e da diminuição da produtividade.

De um modo geral, a produção é predominantemente para autoconsumo e, excetuando o município de Lagoa Nova, os demais possuem baixa diversidade de produtos. O pouco de excedente é comercializado por intermédio de feiras locais, dos mercados institucionais do Programa de Aquisição de Alimentos (PAA) e do
Programa Nacional da Alimentação Escolar (PNAE) do governo federal e de atravessadores.

Segundo os agricultores, a região é propícia ao desenvolvimento de uma grande diversidade de culturas, contudo, estes, na maioria, afirmam não receber assistência técnica.

\subsection{Quadro atual do conhecimento das experiências de inverno}

Entre a população rural do sertão nordestino, em geral, grande parte das pessoas conhece uma técnica ou outra de previsão de tempo (TADDEI, 2006, p. 4). Nas comunidades estudadas dos municípios de Caicó, Acari, Parelhas e Lagoa Nova, localizadas no sertão do Seridó Potiguar, várias pessoas demonstraram ter conhecimento ou já ouviram falar a respeito das "experiências de inverno". Dos 241 entrevistados, 77,2\% afirmaram ter conhecimento ou ouviram falar das experiências, 20,3\% não conheciam ou não ouviram falar e $2,5 \%$ não sabiam ou não responderam.

Embora um alto número tenha declarado conhecer as experiências, nem todos fazem uso destas. Entre aqueles que afirmaram praticar as experiências estão 63,1\% dos entrevistados. Já os que não observam somavam $17 \%$. Os demais não responderam. Estes dados evidenciam o quanto esta prática encontra-se disseminada entre a população estudada.

Identificou-se que as experiências de inverno continuam sendo passadas de geração a geração e a transmissão se dá por intermédio das pessoas mais velhas (pais, avós, entre outros familiares), amigos e pessoas da região, rádio e televisão e através do livro Lunário perpétuo, que é um tipo de almanaque que, segundo MELO (2011/12, p. 109):

[...] trata-se de uma publicação anual, sob o formato de calendário, contendo datas comemorativas, festas móveis e feriados. Apresenta também indicações astrológicas, previsões meteorológicas destinadas aos agricultores, orientações sobre saúde e comportamento, além de curiosidades, provérbios e receitas. Em última instância, os almanaques são livros sobre o tempo, sua medição, sua passagem e trazem, também, a possibilidade de sua (pre)visão. 
A prática da observação das experiências de inverno está intimamente relacionada à idade. $\mathrm{Na}$ área de estudo, o conhecimento e a prática estavam disseminados em todas as faixas etárias dos entrevistados $(18$ a 84 anos de idade), sendo que o maior número, tanto de conhecedores como de quem praticava, estava acima dos 40 anos de idade.

As experiências de inverno identificadas na área de estudo são observadas e outras praticadas, nas quais o sertanejo seridoense faz uso dos sentidos da visão, audição e tato para ler os sinais que a paisagem emite. Os sinais são apreendidos pelos sentidos e em seguida interpretados e testados ao longo do tempo, seguindo um processo de transferência de geração a geração, sendo as pessoas velhas as mais indicadas.

Durante o ano, o sertanejo vê "o primeiro semestre como aquele que iria pôr à prova as predições feitas no ano anterior. $\mathrm{O}$ semestre seguinte prestava-se aos sentidos em estado de prontidão perscrutando céu e terra em busca de evidências empíricas, que alimentavam as esperanças nas chuvas vindouras [...]" (MACEDO, 2012, p. 92). No decorrer das entrevistas, constatou-se que os entrevistados observam as experiências durante praticamente o ano todo, incluindo quase todos os meses do $1^{\circ}$ semestre do ano, em que são verificadas as experiências observadas no $2^{\circ}$ semestre.

O último dia considerado como experiência, em relação ao período adequado à semeadura, é 19 de março, dia de São José. Se nesse dia chover, pode plantar que colhe; agora, se não chover, significa que mesmo que chova dias à frente não será suficiente para a maturação das culturas semeadas. Abril e maio foram citados como meses de observação, contudo, se constituíram em casos esporádicos dentro do universo. As experiências de inverno estão concentradas, em ordem de maior citação, nos meses de novembro, dezembro, outubro, janeiro e setembro (Quadro 1).

O período das chuvas no Seridó é esperado com grande expectativa pelos sertanejos, que aguardam uma quadra chuvosa (período chuvoso que compreende os primeiros meses do ano (fevereiro a maio) que proporcione o bem-estar da vida no sertão do semiárido potiguar. Nesse sentido, as experiências de inverno são uma forma de amenizar a expectativa das chuvas. Ao serem questionados sobre o uso das experiências e sua importância para a vida deles, $50,2 \%$ responderam que estas servem para organizar as atividades no campo, $20,7 \%$ responderam não e $30 \%$ não sabem, não se aplica ou não responderam (NS/NS/NR). Do total de entrevistados, $53,5 \%$ consideram esse conhecimento muito importante, enquanto $14,9 \%$ dizem não ter importância para suas vidas e $31,6 \%$ não opinaram.

\subsection{Experiências de inverno: elementos, sinais indicativos e tipos de previsão}

Os sertanejos elencaram vários elementos que compõem a paisagem dos Sertões do Seridó, os quais são utilizados na previsão do tempo. Conforme citado anteriormente, entre os entrevistados que conhecem ou já ouviram falar das experiências de inverno, 63,1\% têm o hábito de observá-las. A partir da técnica de categorização proposta por Bardin (2010), as experiências puderam ser agrupadas e categorizadas de acordo com a sua natureza.

Dessa forma, as experiências estão categorizadas em oito elementos gerais e os elementos específicos a que correspondem (Figura 2).

QUADRO 1 - PERÍODO DE OBSERVAÇÃO DAS EXPERIÊNCIAS DE INVERNO NOS MUNICÍPIOS DE CAICÓ, ACARI, LAGOA NOVA E PARELHAS, SEGUNDO OS DADOS DA PESQUISA

\begin{tabular}{|c|c|c|c|c|c|c|c|c|c|c|c|c|}
\hline Meses & Nov. & Dez. & Out. & Jan. & Set. & Mar. & Ago. & Jun. & Fev. & Jul. & Maio & Abr. \\
\hline$\%$ & 58,0 & 50,0 & 31,0 & 30,0 & 13,0 & 10,0 & 5,0 & 5,0 & 4,0 & 4,0 & 4,0 & 1,0 \\
\hline
\end{tabular}

$\%$ - Percentual

FONTE: Elaborado pelas autoras, 2012. 


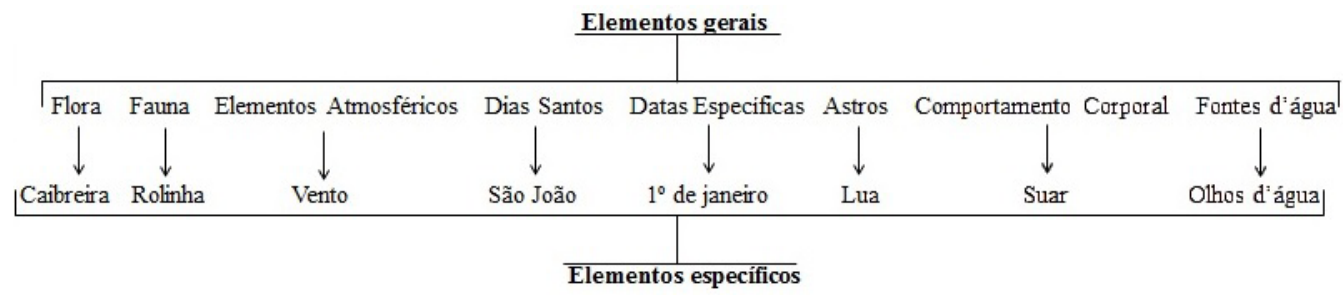

FIGURA 2 - Elementos categorizados a partir das experiências dos sertanejos sobre a paisagem dos Sertões do Seridó. FONTE: Elaborado pelas autoras, 2012.

Vale salientar que a categorização dos elementos gerais é uma classificação das autoras tomando como referência os elementos específicos citados pelos sertanejos seridoenses. A seguir, segue uma breve apresentação das experiências de inverno observadas pelos entrevistados. Os sinais indicativos, que estão entre aspas, são os termos proferidos pelos sertanejos para prognosticar o "inverno"6 e o tempo. Algumas experiências são caracterizadas com termos bem peculiares da região, como, por exemplo, carga/carregar, que se refere aos processos de floração e frutificação das espécies vegetais. A flora e a fauna foram as categorias com maior número de elementos elencados pelos sertanejos.

\subsubsection{Flora}

Sinais de "bom inverno" : Caibreira - quando carrega muito; se florar redondo ${ }^{8}$ e segurar a flor; florar todas [as espécimes] de uma vez; segurar a carga. ${ }^{9}$ Juazeiro segurar a carga; trocar a folhagem. Cajueiro - segurar os frutos; florar redondo; no mês de fevereiro soltar a folha. Aroeira - carregar bem; segurar a carga. Mangueira carregar muito; carregar redondo; segurar a carga. Quixabeira - carregar; se a folha verde amarelar em novembro/ dezembro. Umbuzeiro - quando floresce bem; florar em todos os lados. Barriguda - carregar muito; segurar a carga. Jatobá - segurar a vagem. Seriguela - se nascer os frutos só na madeira; carregar bem (fruto). Mandacaru (Fig. 3) - segurar a carga, carregar bem. Catingueira
(Fig. 4) - produzir muita resina amarela em novembro e dezembro. Embiratanha - segurar a carga. Pau-pedra - carregar muito; segurar a carga. Carnaúba - segurar a carga. Oiticica - produzir frutos; carregar muito.

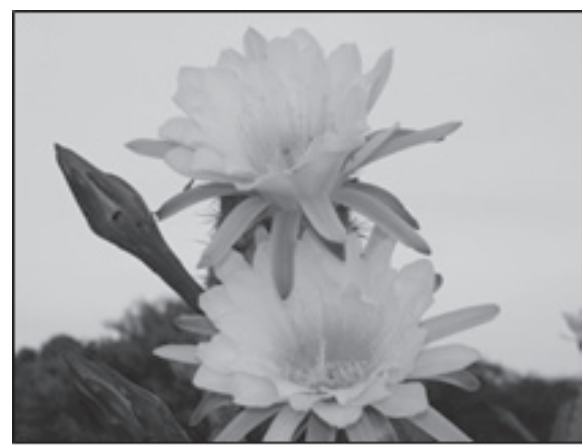

FIGURA 3 - Flor do Mandacaru.

FONTE: Neusiene Silva, 2013.

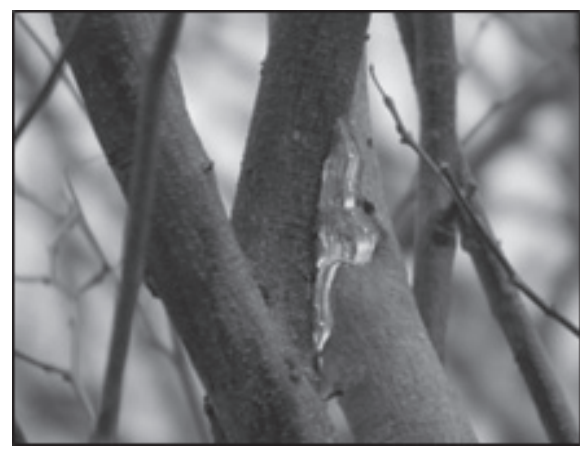

FIGURA 4 - Resina da Catingueira FONTE: Neusiene Silva, 2012.

\footnotetext{
${ }^{6}$ O termo "inverno" na região do Seridó refere-se ao período chuvoso que compreende os meses de fevereiro a maio, mas não tem relação com as estações do ano. ${ }^{7}$ É um inverno que chove de 3 a 4 meses. A precipitação pode chegar de 600 a $900 \mathrm{~mm}$, nasce pastagem abundante para os animais, os açudes enchem, favorece o desenvolvimento da agricultura, havendo muita fartura.

${ }^{8}$ Florar redondo significa que a planta florou igual em todos os seus lados.

${ }^{9}$ Significa que a planta observada segurou a floração e a frutificação, não deixando cair no solo as flores e os frutos antes do período normal de maturação e dispersão da espécie.
} 
Mato - o mato ${ }^{10}$ trocar a folhagem para o natal. Feijão-bravo, Pereiro e Xiquexique - florar. Pau-d'arco - carregar; segurar a carga. Cumaru - carregar; segurar a carga; carregar muito. Jurema - segurar a carga; carregar muito; ao ser cortada nos meses de novembro/dezembro, sair uma água [seiva]; enxerco de jurema ${ }^{11}$ concentrado em um único canto. Angico segurar a carga; produzir resina. Flamboyant - florar em todos os lados. Marizeiro - florar bastante. Sinais do "início do inverno": Juazeiro - o juá (fruto) só cai maduro, no solo, quando está chovendo. Feijão-bravo - só debulha a vagem quando o inverno chega. Sinais de "inverno atrapalhado": ${ }^{12}$ Mangueira - carregar só de um lado. Cajueiro - quando a maioria das castanhas nasce do lado do poente. Sinais de "inverno ruim": 13 Mandacaru - florar na primeira chuva. Umbuzeiro florar de uns lados e outros não. Pereiro - no final do ano, se quebrar um galho e ele estalar. $\underline{\text { Sinais de "inverno }}$ tarde": Cajueiro - demorar a produzir caju. $\underline{\text { Sinais de }}$ seca: Mangueira - carregar pouco. Sinais de "pouca chuva": Juazeiro - o juá (fruto) cair no chão antes de chover. Sinais de "inverno cedo": Juazeiro - se carregar cedo. Sinais que indicam a direção que virá o inverno: Cajueiro - observar o lado que o cajueiro florar (Norte, Sul, Leste, Oeste), se florar do lado Norte o inverno virá do Norte e etc. Sinais de chuva próxima: Mandacaru quando flora na seca.

\subsubsection{Fauna}

Sinais de "bom inverno": Rolinha ${ }^{14}$ (Fig. 5) - fazer ninhos; pôr muito; fazer seu ninho sobre as plantas. Fura-barreira ${ }^{14}$ - fizer a entrada dos ninhos na direção norte. Mocó ${ }^{15}$ - crescer o rabo; se estiver magro; reproduzindo em novembro/dezembro. João-de-barro ${ }^{14}$ - quando faz muitos ninhos; fizer o ninho com a entrada para o poente (Oeste). Formiga ${ }^{16}$ - quando faz os ninhos nos altos; formiga-de-roça preta criar asas; formiga Alemanha sair do porão dos açudes em direção aos altos. Tatu ${ }^{15}$ - reproduzindo. Caboré ${ }^{14}$ - cantar durante a noite. Gato doméstico ${ }^{15}$ - reproduzindo em dezembro. Tetéu ${ }^{14}$ - sair do meio do rio; pôr no tabuleiro longe da água. Abelhas ${ }^{16}$ - se o enxu verdadeiro tiver com muitos "filhotes" e sem mel; quando tem muita abelha. Lagarta de pedra ${ }^{15}$ - no começo de inverno encontrar muitas lagartas sob as pedras. Cururu (sapo) $)^{17}$ - "cantar" no período seco (emissão de som). Carão ${ }^{14}$ - cantar. Gado ${ }^{15}$ - quando nasce bezerro macho. Preá ${ }^{15}$ (Fig. 6) - crescer o rabo; reproduzir em novembro/dezembro. Guiné ${ }^{14}$ começar a pôr em novembro.

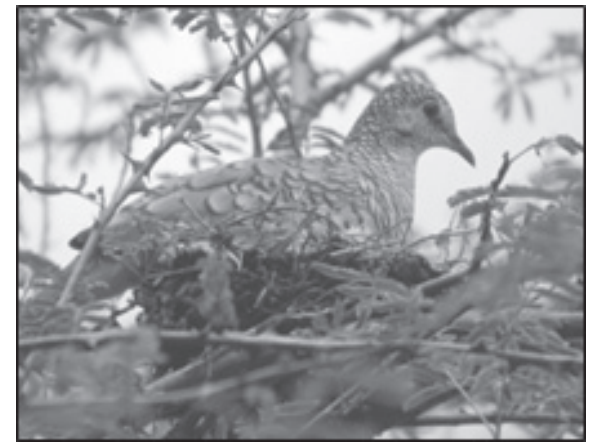

FIGURA 5 - Rolinha cascavilinha no ninho. FONTE: Neusiene Silva, 2012.

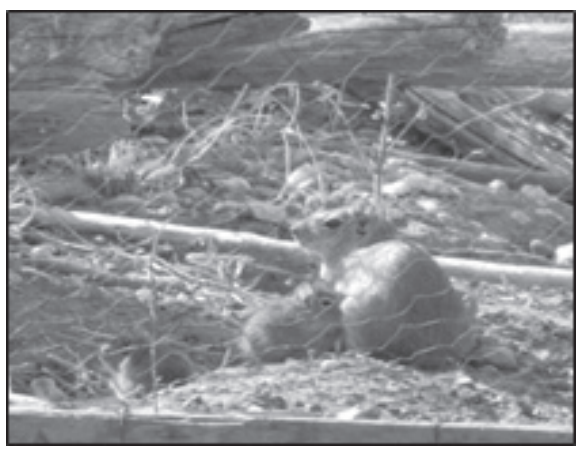

FIGURA 6 - Preá com filhotes.

Fonte: Neusiene Silva, 2012.

\footnotetext{
${ }^{10}$ Refere-se à vegetação.

${ }^{11}$ Planta parasitária que, pelos relatos dos entrevistados, é encontrada sobre espécimes de jurema-preta.

${ }^{12}$ É um "inverno" cheio de veranicos chovendo um mês e outro não, por exemplo. Chove fora do tempo, ou seja, quando não é no período correto para a semeadura.

${ }^{13}$ É o "inverno" que não acontece, dá algumas chuvas e não chove mais. Está bem próximo de uma seca, mas não chega a ser literalmente.

${ }^{14}$ Ave.

${ }^{15}$ Mamífero.

${ }^{16}$ Inseto.

${ }^{17}$ Anfíbio.
} 
Papa-sebo ${ }^{14}$ - reproduzindo no final do ano. Peixe - curimatã estiver ovada no final do ano; peixes ovados. Sabiá $^{14}$ - cantar no final do ano. Coruja ${ }^{14}$ - pôr muito. Mãe-da-lua ${ }^{14}$ - cantar de madrugada. Gavião vermelho ${ }^{14}$ - sair da serra e sentar no chão. Sinais de chuva próxima: ${ }^{18}$ Fura-barreira - se cantar chove depois de três dias. Caboré - quando começa a cantar. Formiga ${ }^{16}$ - quando as formigas pretas criam asas e ficam assanhadas. Abelhas - quando procuram as casas abandonadas. Cururu (sapo) e rã ${ }^{17}$ - quando eles "cantam" (emissão de som). Muriçoca ${ }^{16}$, mosca ${ }^{16}$ e maribondo ${ }^{16}$ - se aproximar das casas (entre janeiro e março). Sinais de inverno próximo: Cupim ${ }^{16}$ - cupinzeiro estiver com muitos "filhotes"; reformar o cupinzeiro com mais barro; criar asa. Carão ${ }^{14}$ - cantando no açude. Sinais de "inverno ruim": Mocó ${ }^{15}$ : se estiver gordo. Preá - se estiver com o saco vazio ${ }^{19}$ (testículos). Guiné - pôr no chão sem ninho. Peixe - o peixe desovar na primeira chuva. Tejo ${ }^{20}$ - não sair de dentro da toca. Sinais de "inverno cedo": Rouxinol $^{14}$ - fizer ninho no telhado das casas em novembro. Cururu (sapo) - começar a cantar cedo. Camaleão ${ }^{20}$ - quando ele se enterra. Sinais de "inverno fraco":21 Abelhas - o enxu verdadeiro tiver muito mel e poucos "filhotes". Rolinha - pôr no chão. Sinais de "inverno tarde": Fura-barreira - fizer a entrada do ninho para o nascente (Leste). Sinais do nível de água nos corpos d'água: Fura-barreira - o local do ninho na barreira do rio/riacho indica o nível que a água poderá chegar. Sinais de "inverno prolongado": Cigarra ${ }^{16}$ - quando chovendo, ela cantar muito. Sinais de seca prolongada: Cigarra - se tiver na seca e ela cantar muito. Sinais de seca: Maribondo - não aparecer nas casas das pessoas. Tatu $^{15}$ - não reproduzir. Sinais de veranicos: Formiga se a tanajura cair e passar três dias sem chover significa que vai demorar a chover novamente. Sinais de chuva para o mesmo dia: Formiga - quando as formigas se escondem. Sinais de tempestade: Gado - colocar o focinho no chão, cheirar a terra e olhar para o pasto. Sinais do início das chuvas: Cajaquinha ${ }^{14}$ - se fizer o ninho dentro da manga do gado, demora a chover.

\subsubsection{Elementos Atmosféricos}

Sinais de "bom inverno": Redemoinhos - ocorrências de muitos redemoinhos no final do ano. Frio: nas madrugadas do final do ano fizer frio. Relâmpagos - relampejando para o poente; relampejando no Ceará no final do ano. Chuva - ocorrência de chuvas no final do ano. Vento - soprando do Norte, do Nordeste para o Sul, do poente (Oeste) para o nascente (Leste); soprando forte; ventando forte no final do ano. Sinais de chuva próxima: Temperatura: quando a temperatura do dia aumenta e fica abafada. Relâmpagos - ocorrência de relâmpagos. Sinais de "inverno ruim": Vento: no final do ano e início do outro ventar do Sul para o Norte. Sinais de chuva imediata: Vento - vento forte do poente, mais ocorrências de redemoinhos e de repente parar de ventar. Sinais de ocorrência de chuvas: Nuvem Mariana - se a nuvem Mariana passar com dois meses chove. Sinais de seca: Relâmpagos - relampejando para o nascente.

\subsubsection{Dias santos}

Sinais de "bom inverno": São João (24 de junho) - se a cinza da fogueira estiver durinha sem estar espalhada; se enterrar uma garrafa com água sob a fogueira e ela sangrar. ${ }^{22}$ Corpus Christi - se tiver preparação do tempo para chuva. Nossa Senhora Aparecida (12 de outubro) - se tiver preparação para chuva. Nossa Senhora da Luz (2 de fevereiro) - ocorrência de relâmpagos. Nossa Senhora da Conceição ( 8 de dezembro) - se chover; se relampejar. Santa Luzia (13 de dezembro) - tiver carregação do tempo ${ }^{23}$ na véspera e no dia. São Sebastião (20 de janeiro) - serenar ou ficar nublado. São José (19

\footnotetext{
${ }^{18}$ Estes sinais revelam que já está bem próximo de chover, podendo ser uma questão de poucos dias.

${ }^{19}$ Testículos secos.

${ }^{20}$ Réptil.

${ }^{21}$ É um inverno bem abaixo da média.

${ }^{22}$ Transbordar.

${ }^{23}$ Refere-se à preparação do tempo para chuva, como a formação de nuvens, ocorrência de relâmpagos e trovões etc.
} 
de março) - ocorrência de chuvas. $\underline{\text { Sinais de "inverno }}$ fraco": São Pedro (29 de junho) e São João - chover no dia desses santos. Sinais de seca: São João - se enterrar uma garrafa com água sob a fogueira e ela diminuir a água. Sinais de "inverno ruim": São João - se a cinza da fogueira estiver espalhada.

\subsubsection{Datas específicas}

Sinais de "bom inverno": $\mathbf{1}^{\mathbf{0}}$ de janeiro - se todos os pássaros cantarem de manhã bem cedo; se o sol nascer por trás de uma nuvem (barra de dia de ano); chover; o sol nascer amarelo. Finados (2 de novembro) - se tiver preparação para chuva. 4 de outubro - o sol se pôr vermelho e bem grande com uma névoa na frente. Lua cheia e nova de outubro - têm que estar com as pontas viradas para o norte. 18 de outubro - o sol nascer por trás de uma nuvem; se relampejar. 7, 17 e 27 de janeiro - se chover. $\mathbf{1}^{\mathrm{a}}$ lua de janeiro - se nascer por trás de uma barra (nuvem); for cheia ou nova. Sinais de "inverno atrapalhado": $\mathbf{1}^{\text {a }}$ lua de janeiro - se a $1^{\text {a }}$ lua nascer limpa, sem nenhuma nuvem em frente. Sinais de "inverno ruim": $\mathbf{1}^{\mathrm{a}}$ lua cheia de janeiro - nascer vermelha e limpa (sem nuvens). $\mathbf{1}^{\mathbf{0}}$ de janeiro - o sol nascer vermelho. $\mathbf{2}$ de janeiro - quando o sol nascer estiver ventando muito.

\subsubsection{Astros}

Sinais de "bom inverno": Cruzeiro do sul $^{24}$ quando o cruzeiro está manchado. Sol - se se pôr vermelho no final do ano. Barquinha de Noé24 - se nascer às 6 ou 7 horas no Norte. Estrela-d'alva - se viajar para o norte. Sinais de seca: Estrela-d'alva - se viajar para o sul. Sinais de inverno próximo: Lua - quando a lua está mais para o norte. Sinais de ocorrência de vento: Lua - se tiver a bulandeira ${ }^{25}$ de cor cinza em volta da lua. Sinais de dia quente: Lua - se tiver a bulandeira de cor vermelha.

\subsubsection{Comportamento corporal}

Sinais de "bom inverno": Suar - se estiver tirando leite no curral de madrugada e suar a camisa. Sinais de chuva próxima: Suar - se sentir muito calor e suar até pingar chove com três dias.

\subsubsection{Fontes d'água}

Sinais de "bom inverno": Olho d'água-se no final do ano encher ou aumentar o nível da água.

Os sertanejos sempre observavam os mesmos elementos. Por vezes, os sinais indicativos e o tipo de previsão (seca, inverno "bom"/"ruim" etc.) em relação a um mesmo elemento (sol, lua, abelhas etc.) variavam de entrevistado para entrevistado.

Nesse sentido, a percepção dos elementos de uma paisagem pode ser realizada de forma distinta por cada ser humano. Isso acontece devido à apreensão ser seletiva. Desse modo, cada pessoa pode apresentar uma interpretação sobre um mesmo fato (SANTOS, 1997; TUAN, 1983).

Como se enfatizou anteriormente, a percepção da paisagem, por si só, ainda não se constitui no conhecimento. Para isso, é necessária a interpretação do sujeito sobre o que se está observando (SANTOS, 1997; TUAN, 1983). Sendo a interpretação um processo individual, o modo como se vê e interpreta a realidade é diferenciado em cada sujeito. Mesmo havendo, por vezes, divergências na forma de observar os mesmos elementos da paisagem seridoense, os sertanejos apresentam muitas convergências.

\subsection{O papel das experiências no modo de vida dos sertanejos}

Dos 241 entrevistados, 129 afirmaram que as experiências são importantes, sendo possível identificar as possíveis funções que as experiências de inverno exercem na vida dos sertanejos seridoenses. Na sequência, o Quadro 2, com as funções categorizadas a partir da fala dos sertanejos.

\footnotetext{
${ }^{24}$ Constelação.

${ }^{25}$ É um círculo de cores em torno do sol e da lua, de cor cinza, e às vezes aparece com cores semelhantes às do arco-íris (halo solar e halo lunar).
} 
QUADRO 2 - FUNÇÃO DAS EXPERIÊNCIAS DE INVERNO PARA O SERTANEJO SERIDOENSE DAS COMUNIDADES RURAIS DOS MUNICÍPIOS DE ACARI, CAICÓ, PARELHAS E LAGOA NOVA

\begin{tabular}{|c|c|c|}
\hline $\begin{array}{l}1 \text { - Aprendizagem/sentimento de pure- } \\
\text { za da natureza }\end{array}$ & 2 - Fé em Deus & 3 - Contemplação da natureza \\
\hline $\begin{array}{l}\text { "Eu faço essas experiências mais de uma } \\
\text { vez e acontece. Então é como ser profes- } \\
\text { sor" / "Porque eu estudo a natureza e vejo } \\
\text { que ela não tem maldade". }\end{array}$ & $\begin{array}{l}\text { Porque tem fé em Deus / "Porque deixa na } \\
\text { lembrança de outras pessoas. Quando eu faço } \\
\text { me lembro de Deus"! }\end{array}$ & $\begin{array}{l}\text { "É importante... é importante porque é coisa } \\
\text { da natureza" / Porque ela é uma pessoa de } \\
\text { idade ligada à natureza. }\end{array}$ \\
\hline 4 -Sentimento de alegria e esperança & 5 - Organização do trabalho & 6 - Prevenção ${ }^{26}$ \\
\hline
\end{tabular}

FONTE: Elaborado pelas autoras, 2012.

Mas, se por um lado as experiências são reproduzidas sistematicamente por essa população, há também aqueles que observam mudanças nesse processo. Foram vários os relatos em que tal condição pôde ser observada: "Antes de o homem estudar era isso que valia para agricultura". / "Antes era mais importante, que se plantava mais". / "Já foi importante, mas agora o sistema está mudando, antes não tinha as previsões da TV".

De um modo geral, identificou-se que as experiências têm função mais subjetiva do que essencialmente prática. Estas têm a função de criar laços de conhecimento e aprendizagem entre a natureza e o homem; por vezes, o sertanejo é o professor e a natureza a mestra, por outras, ele é apenas aluno; de intermediar a fé em Deus; fornecer alegria e esperança no desejo de um ano vindouro próspero de muitas chuvas; de organizar as atividades do campo através do manejo do roçado, na decisão do tamanho da área a ser cultivada e na compra de animais. As experiências atuam, também, como preventivas dos possíveis efeitos das secas, fazendo com que os agricultores antecipem a venda de animais. Quando os sinais das experiências são positivos, ou seja, indicam chuva, significa que haverá fartura para a população e para os animais.

A função primordial das experiências de inverno é a previsão, contudo, nem todos os sertanejos observam a paisagem com a finalidade única de prever o tempo. O sertanejo observa as experiências de inverno também para manter uma relação de proximidade com a natureza (aprendizagem/sentimento de pureza) e para admirá-la (contemplação da natureza). Por sua vez, as experiências geralmente exercem mais de uma função para o sertanejo.

\footnotetext{
${ }^{26}$ As categorias previsão e prevenção, nesse contexto, têm sentidos diferentes. Previsão refere-se aos entrevistados que observam as experiências para saber a condição meteorológica, mas não necessariamente usam para se prevenir de possíveis efeitos de uma seca. Prevenção são os que observam com o objetivo de se prevenir e não apenas de prever e saber a condição do tempo.
} 
Dos entrevistados que conhecem/ouvem ou observam as experiências, $50 \%$ alegam usar os prognósticos para organizar suas atividades. Mas, verificou-se que as experiências de inverno têm a função principal de dar mais ânimo, esperança e reduzir a ansiedade dos seridoenses do que propriamente preveni-los ou ajudá-los a planejar suas ações visando aumentar sua produção e/ou evitar possíveis prejuízos advindos das secas.

A afirmação de Macedo (2012, p. 92) vem ratificar essa função, ao indicar ser a experiência "uma forma, sem dúvida, de convivência com a imperiosa certeza das estiagens que se plasmou em artes divinatórias servindo mais à esperança que a atitude de prevenção". Os prognósticos são sempre realizados na expectativa de um bom inverno e quando estas se configuram em predições negativas, os sertanejos preferem acreditar em Deus, pois somente este poderia mudar o quadro previsto.

Constatou-se entre os entrevistados que está ocorrendo uma redução das atividades agrícolas em relação a outros períodos. A situação que se instala se deve a fatores relacionados principalmente à falta de recursos e/ou acesso ao crédito para investir no desenvolvimento de suas atividades. O clima e as condições meteorológicas da região são outras dificuldades bastante relatadas. As altas temperaturas e as irregularidades pluviométricas (excesso ou a ausência de chuvas) dificultam a produção, levando muitas vezes a prejuízos e desestimulando o homem do campo.

Dificuldades na comercialização, terras fracas ou degradadas, diminuição da produtividade, condições físicas das estradas, pragas, falta de mão de obra e equipamentos, difícil acesso à terra, falta de incentivo do governo, pouco acesso à energia elétrica, custo de energia elevado, entre outras, completam o quadro dos obstáculos elencados pelos sertanejos.

Esses fatores sumariamente contribuem para desestimular a atividade agrícola no universo pesquisado. Já a pecuária, por ser uma atividade de colonização do Seridó, constituiu-se como um dos tripés de sua economia na história e permanece disseminada entre os criadores. Dos 241 entrevistados, 144 afirmam desenvolver a pecuária. A atividade atua como "poupança viva", ou seja, em casos de necessidades, esses animais são vendidos para comprar ou investir em algum empreendimento.

A história da região permitiu que a pecuária se configurasse, entre os entrevistados, como uma atividade tradicional. Nesse sentido, é importante para o sertanejo, porém, mais que uma condição meramente econômica, é a satisfação de ter em sua propriedade, pelo menos, algumas cabeças de gado. A terra impõe para os mesmos a necessidade de ocupação, e esta, no momento que não é ocupada com algum tipo de criação ou outra atividade, perde seu sentido e seu valor.

Por outro lado, as ações e políticas de convivência com o semiárido (emergências, frentes de trabalho, política de açudagem, desenvolvimento de tecnologias de armazenamento de água, bolsa seca, entre muitas outras), os benefícios sociais do governo (bolsa-família, aposentadorias) e o desenvolvimento de outras atividades no campo (pluriatividade) têm contribuído para a redução da vulnerabilidade dos entrevistados face às adversidades ambientais.

$\mathrm{Na}$ área de estudo, observou-se que a população é constituída principalmente por pessoas mais velhas porque seus parentes (filhos) comumente migraram para as cidades do Rio Grande do Norte ou para outros Estados, geralmente por três motivos: em busca de trabalho, casar ou estudar. Dessa forma, falta mão de obra para trabalhar na agricultura. Os entrevistados, em grande parte, têm aposentadoria, recebem benefícios do governo (bolsa-escola) e desenvolvem mais de um tipo de atividade. Para a maioria dos entrevistados, a renda externa (aposentadoria, bolsa-escola, etc.) é maior que a gerada dentro do estabelecimento (fazenda, sítio, propriedade).

Diante desse quadro, os prognósticos meteorológicos vão perdendo a função prática de prever chuva ou seca visando ajudar o sertanejo seridoense a se prevenir contra os efeitos da estiagem e/ou organizar o sistema produtivo, aumentando a área de plantio, cultivando o roçado, comprando bovinos, ovinos, caprinos etc. Conhecer a condição meteorológica futura, de certo modo, já não é tão necessário porque o sertanejo seridoense não depende exclusivamente do seu trabalho na terra para sobreviver. 


\subsection{Sertanejo $x$ meteorologistas}

Os entrevistados afirmaram que, nos últimos anos, está ocorrendo redução na frequência dos anos secos. Quando questionados, no mês de novembro de 2011, sobre a condição pluviométrica de 2012, a maioria respondeu que até aquele momento as previsões estavam indicando um ano de "bom inverno", enquanto a minoria afirmava que os sinais da natureza estavam indicando um ano de seca e/ou atrapalhado/tardio (Quadro 3).

Todas as previsões mostravam um ano regular de inverno, tanto pelos sertanejos como pela Empresa de Pesquisa Agropecuária do Rio Grande do Norte (EMPARN). Em notícias divulgadas pelo jornal Tribuna do Norte, em janeiro de 2012, a EMPARN previa um ano regular de chuvas, com estimativas pluviométricas de 600 a $700 \mathrm{~mm}$ para o semiárido potiguar (ATUAÇÃO, Tribuna do Norte, 2012). Mas, o parecer final só seria divulgado após reunião a ser realizada em Natal, no mês de fevereiro de 2012.

Após a reunião de meteorologistas de todo o país, em Natal/RN, na $4^{\mathrm{a}}$ Reunião de Análise Climática para a Região Nordeste, foi concluído que, entre os meses de março a maio, o volume de chuvas ficaria entre 500 e 650 $\mathrm{mm}$, constituindo-se num inverno regular (INVERNO, Tribuna do Norte, 2012). Mas, o que aconteceu foi um quadro assolador de seca em todo o sertão potiguar e em outros Estados do Nordeste.

Não significa que as previsões da EMPARN e dos agricultores não tenham credibilidade em cada contexto em que se aplicam. Isso mostra que a situação meteorológica do Nordeste não é fácil de prever, até mesmo para os meteorologistas que dispõem de grande aparato tecnológico. Ou seja, tanto uma previsão como a outra são passíveis de erros. Parte dos entrevistados mostrou-se bastante confiante nas previsões dos meteorologistas, o que mostra a influência dos meios de comunicação em massa (rádio e televisão). Há certa resistência por parte de alguns agricultores em acreditar nas previsões dos meteorologistas, mas estão ocorrendo mudanças de pensamento (Quadro 4).
QUADRO 3 - PREVISÃO METEOROLÓGICA PARA 2012 PELOS SERTANEJOS A PARTIR DAS EXPERIÊNCIAS DE INVERNO EM NOVEMBRO DE 2011

\begin{tabular}{|c|c|}
\hline Categorias & $\%$ \\
\hline Inverno $^{27}$ & 59,5 \\
\hline Inverno fraco $^{\text {Seca }}$ & 4,5 \\
\hline Inverno tardio & 4,5 \\
\hline NS/NR & 1,5 \\
\hline
\end{tabular}

QUADRO 4 - PERCENTUAL DOS ENTREVISTADOS QUE ACREDITAM OU NÃO NAS PREVISÕES METEOROLÓGICAS QUE SÃO DIVULGADAS PELO RÁDIO E TELEVISÃO

\begin{tabular}{|c|c|}
\hline Categorias & $\%$ \\
\hline Sim & 57,3 \\
\hline Não & 22,8 \\
\hline Outra & 10,8 \\
\hline NS/NR & 9,1 \\
\hline
\end{tabular}

NS/NR - Não sabe ou não respondeu.

A maioria dos entrevistados acredita nas previsões dos meteorologistas, argumentando que os acertos das previsões meteorológicas vêm se acumulando ao longo dos anos. Outros justificam que as previsões, por serem fundamentadas em estudos científicos, são mais confiáveis. Todavia, observou-se o predomínio da fé em Deus, independente de estas se concretizarem ou não. Conforme o relato de alguns entrevistados: "Deus é quem sabe" / "só acredita em Deus" / "é Ele quem sabe de tudo" / "Não tem quem sabe, é Deus quem manda" / "Mas é porque estudaram pra isto. Mas é só Deus quem sabe".

Os usos destas experiências estão mais direcionados a preencher a vida sertaneja de esperança que propriamente fornecer um prognóstico que auxilie na organização do seu trabalho no campo.

\section{Considerações finais}

$\mathrm{Na}$ atualidade, as experiências de inverno têm a função para os sertanejos seridoenses, habitantes da zona rural dos municípios de Acari, Caicó, Parelhas e

\footnotetext{
${ }^{27}$ Vale ressaltar novamente que inverno refere-se ao período chuvoso da região (fevereiro a maio) e não à estação do ano.
} 
Lagoa Nova, de ser uma das "[...] poucas esperanças que o sertanejo guarda para nutrir sua existência [...]" (MACEDO, 2012, p. 91). Estes são conhecimentos que, mesmo diante dos processos de modernização tecnológica das previsões meteorológicas, ainda encontram-se bastante disseminados.

Salienta-se que, entre os entrevistados, a prática agrícola é quase sempre realizada com os mesmos tipos de culturas, em especial milho e feijão, e para aqueles que relataram fazer uso das experiências na organização do trabalho, estariam relacionadas principalmente à produção agrícola no que diz respeito ao preparo do solo (limpeza, cortar/arar a terra dos roçados) e estimar a produção para semeadura das sementes. Mais do que permitir ao homem do campo uma organização do trabalho em relação à previsão do tempo, as experiências são elos do homem com a natureza, do seu ser com Deus, do desejo de desvendar os segredos da natureza e do futuro próximo, que são intensificados nos meses finais e confirmados no início de cada ano. É esse elo

\section{Referências}

AB'SÁBER, A. N. Os domínios de natureza do Brasil: potencialidades paisagísticas. São Paulo: Ateliê Editorial, 2003.

ALBUQUERQUE JR., D. M. A invenção do Nordeste e outras artes. Recife: FJN. Ed. Massangana; São Paulo: Cortez, 1999.

ALMEIDA, A. V. Prescrições zooterápicas indígenas nas obras de Guilherme Piso (1611-1678). In: ALVES, Ângelo Giuseppe Chaves et al. (Org.). Atualidades em Etnobiologia e Etnoecologia, v. 2. Recife: NUPEEA/Sociedade Brasileira de Etnobiologia e Etnoecologia, 2005.

ARAÚJO, H. F. P. de; LUCENA, R. F. P. de; MOURÃO, J. da S. Prenúncio de chuvas pelas aves na percepção de moradores de comunidades rurais no município de Soledade - PB, Brasil. Interciência, Caracas, Venezuela: Asociación Interciência, v. 30, n. 12, p. 764-769, dec. 2005. Disponível em: <http:// redalyc.uaemex.mx/pdf/339/33911108.pdf>. Acesso em: maio 2011.

ATUAÇÃO de La Niña favorece inverno no sertão nordestino. Tribuna do Norte On-line. Natal, 12 de jan. 2012. Disponível $\mathrm{em}:<$ http://tribunadonorte.com.br/noticia/atuacao-de-la-nina-favorece-inverno-no-sertao-nordestino/208781>. Acesso em: jul. 2012. que mantém vivo o conhecimento tradicional das experiências de inverno até mesmo para aqueles sertanejos que migraram para as cidades interioranas e litorâneas, longe da caatinga e do campo, mas que guardam tais experiências vivas na memória.

\section{Agradecimentos}

Ao DAAD (Deutscher Akademischer Austausch Dients - German Academic Exchange Service) pelo financiamento da pesquisa.

Aos professores e alunos do Laboratório de Estudos Rurais da UFRN pelo apoio incondicional ao desenvolvimento do trabalho.

À Rede Clima e a Sub-rede Mudanças Climáticas e Desenvolvimento Regional de responsabilidade do Centro de Desenvolvimento Sustentável (CDS/UnB), pela parceria na execução das atividades de campo.

BARDIN, L. Análise de conteúdo. Lisboa: Edições 70, 2010.

BERQUE, A. Paisagem-marca, paisagem-matriz. In: CORREAA, R. L.; ROSENDAHL, Z. (Orgs.). Paisagem, tempo e cultura. Rio de Janeiro: EdUERJ, 1998.

BRUNO, F.; MARTINS, K. P. H. Profetas da natureza: ver e dizer no sertão. Intexto, Porto Alegre: UFRGS, v. 1, n. 18, p. 1-12, jan./jun. 2008. Disponível em: $<$ http://www.seer.ufrgs.br/ intexto/article/download/6734/4036>. Acesso em: dez. 2011.

COSGROVE, D. A geografia está em toda parte: cultura e simbolismo nas paisagens humanas. In: CORREAA, R. L.; ROSENDAHL, Z. (Orgs.). Paisagem, tempo e cultura. Rio de Janeiro: EdUERJ, 1998.

DIEGUES, A. C.; ARRUDA, R. S. V. (Orgs.). Saberes tradicionais e biodiversidade no Brasil. Brasília: Ministério do Meio Ambiente; São Paulo: USP, 2001. (Biodiversidade, 4).

FARIA, O. L. de. Sertões do Seridó. Brasília: [s.n.], 1980.

FOLHES, M. T., DONALD, N. Previsões tradicionais de tempo e clima no Ceará: o conhecimento popular a serviço da ciência. Sociedade \& Natureza, Uberlândia, v. 19, n. 2, p. 19-31, dez. 2007. Disponível em: <http://www.sumarios. 
org/resumo/previs\%C3\%B5es-tradicionais-de-tempo-eclima-no-cear\%C3\%A1-o-conhecimento-popular-\% $\%$ C3\%A0servi $\% \mathrm{C} 3 \% \mathrm{~A} 7 \mathrm{o}-\mathrm{da}-\mathrm{ci} \% \mathrm{C} 3 \% \mathrm{AAncia}->$. Acesso em: maio 2011.

GUERRA, P. B. A civilização da seca. Fortaleza: DNOCS, 1981.

GUILLEN, I. C. M. Sertão e a identidade nacional em Capistrano de Abreu. In: BURITY, Joanildo A. (Org.). Cultura e identidade: perspectivas interdisciplinares. Rio de Janeiro: DP\&A, 2002. p. 105-123.

INVERNO terá chuvas regulares. Tribuna do Norte on-line. Natal, 18 de fev. 2012. Disponível em: <http://tribunadonorte. com.br/noticia/inverno-tera-chuvas-regulares/212404>. Acesso em: jul. 2012.

LUCENA, R. F. P. de et al. A flor chegou, chuva avisou: meteorologia popular no semiárido paraibano. In: ALVES, Giuseppe Chaves; LUCENA, Reinaldo Farias Paiva de; ALBUQUERQUE, Ulysses Paulino de (Orgs). Atualidades em Etnobiologia e Etnoecologia. v. 2. Recife: NUPPEEA/Sociedade Brasileira de Etnobiologia e Etnoecologia, 2005. p. 171-182.

MACEDO, M. K. de. A penúltima versão do Seridó: espaço e história do regionalismo seridoense. 1988. 200 f. Dissertação (Mestrado em Ciências Sociais) - Universidade Federal do Rio Grande do Norte, Natal, 1998.

A penúltima versão do Seridó: espaço e história do regionalismo seridoense. Natal: EDUFRN; Campina Grande: EDUEPB, 2012.

MAGAlHÃES, J. Previsões folclóricas das secas e dos invernos do Nordeste. Brasileiro. Imprensa Universitária do Ceará. Fortaleza-CE. 1963, p. 98-137. In: ROSADO, Vinght-un; ROSADO, América (Sel. e Org.). $12^{\circ}$ Livro das secas. Edição especial para o acervo virtual Oswaldo Lamartine de Faria. Disponível em: $<$ http://www.colecaomossoroense.org. br/acervo/12_livro_das_secas.pdf $>$. Acesso em: mai. 2011.

MAIA, G. N.. Caatinga: árvores e arbustos e suas utilidades. São Paulo: D\&Z Computação Gráfica e Editora, 2004.

MARQUES, J. G. W. "É pecado matar a esperança, mas todo mundo quer matar o sariguê". Etnoconservação e catolicismo no Brasil. In: ALVES, Ângelo Giuseppe Chaves et al. (Org.). Atualidades em Etnobiologia e Etnoecologia. v. 2. Recife: NUPEEA/Sociedade Brasileira de Etnobiologia e Etnoecologia, 2005. p. 25-43.

MELO, R. A. de. Almanaques de cordel: do fascínio da leitura para a feitura da escritura, outro campo de pesquisas. Revista IEB, n. 2, p. 107-122, set. 2011/mar. 2012.
MOLION, L. C. B.; BERNARDO, S. O. Uma revisão da dinâmica das chuvas no nordeste brasileiro. Revista Brasileira de Meteorologia, v. 17, n. 1, p. 1-10, 2002. Disponível em: <http:// www.rbmet.org.br/port/revista/revista_artigo.php?id_arti$\mathrm{go}_{\mathrm{O}}=548>$. Acesso em: maio 2011 .

MORAIS, I. R. D. Seridó Norte-rio-grandense: uma geografia da resistência. Caicó: Ed. do autor, 2005.

ROQUE, A. Potencial de uso dos recursos vegetais em uma comunidade rural do semiárido do Rio Grande do Norte. 2009. 79 f. Dissertação (Mestrado em Desenvolvimento e Meio Ambiente) - Universidade Federal do Rio Grande do Norte, Natal (RN), 2009.

SAMPAIO, E.; RODAL, M. D. J. Fitofisionomia da caatinga. (Documento para discussão no GT Botânica). In: . Avaliação e identificação de ações prioritárias para a conservação, utilização sustentável e repartição dos benefícios da biodiversidade do bioma caatinga. Petrolina, 2000. Disponível em: <http://www.biodiversitas.org.br/caatinga/relatorios/ fitofisionomias.pdf>. Acesso em: maio 2012.

et al. (Eds.). Vegetação e flora da caatinga. Contribuição ao Workshop Avaliação e Identificação de Ações Prioritárias para a Conservação, Utilização Sustentável e Repartição dos Benefícios da Biodiversidade do Bioma Caatinga, em Petrolina, 5/2000. Recife: Associação Plantas do Nordeste - APNE; Centro Nordestino de informações sobre plantas CNIP, 2002 apud MAIA, Guerda Nickel. Caatinga: árvores e arbustos e suas utilidades. São Paulo: D\&Z Computação Gráfica e Editora, 2004.

SANTOS, A. A. dos. Quando há seca no sertão. [S.l.: s.n.], 1981. 8. p. Literatura de Cordel.

SANTOS, M. Metamorfoses do espaço habitado: fundamentos teóricos e metodológicos da geografia. 5 ed. São Paulo: Hucitec, 1997.

SANTOS, M. C. dos. As grandezas do sertão. Campina Grande, PB: A Estrela da Poesia, [19--]. 15 p. Literatura de Cordel.

SAUER, C. O. A morfologia da paisagem. In: CORRÊA, R. L.; ROSENDAHL, Z. (Orgs.). Paisagem, tempo e cultura. Rio de Janeiro: EdUERJ, 1998.

SILVA, N. M. Experiências de inverno no Seridó Potiguar. Dissertação (Mestrado no Programa Regional de Pós-Graduação em Desenvolvimento e Meio Ambiente - PRODEMA). Universidade Federal do Rio Grande do Norte, Natal, 2013. (não publicada).

SILVA, R. M. A. da. Entre dois paradigmas: combate à seca e convivência com o semi-árido. Sociedade e Estado, Brasília, v. 
18, n. 1/2, p. 361-385, jan./dez. 2003. Disponível em: <http:// www.scielo.br/pdf/se/v18n1-2/v18n1a16.pdf $>$. Acesso em: abr. 2012.

TADDEI, R. Oráculos da chuva em tempos modernos: mídia, desenvolvimento econômico e as transformações na identidade social dos profetas do sertão In: MARTINS, Karla Patricia Holanda (Org.). Profetas da chuva. Fortaleza: Tempo Dimagem, 2006.
Os profetas da chuva do sertão como produção midiática. Escola de Comunicação da Universidade Federal do Rio de Janeiro. In: REUNIÃO ANUAL DA LATIN AMERICAN STUDIES ASSOCIATION, 2009, Rio de Janeiro, 11 a 14 de junho. [Trabalho apresentado]. Disponível em: $<$ http://lasa. international.pitt.edu/members/congress-papers/lasa2009/files/ TaddeiRenzo.pdf $>$. Acesso em: maio de 2011.

TUAN, Y. Espaço e lugar: a perspectiva da experiência. Tradução de Lívia de Oliveira. São Paulo: DIFEL, 1983. cap. 2.

Recebido em 9 de novembro de 2012. Aceito em 3 de abril de 2013. Publicado em junho de 2013. 